\title{
Haematology and Serum Characteristics of African Catfish (Clarias gariepinus Burchell) Fed Graded Levels of Tigernut Based Diet
}

\author{
L. A. Agbabiaka ${ }^{* 1}$, F. N. Madubuike ${ }^{2}$ and B. U. Ekenyem ${ }^{2}$ \\ ${ }^{1}$ Department of Fisheries Technology, Federal Polytechnic, Nekede, Owerri, Nigeria. \\ ${ }^{2}$ Department of Animal Science and Fisheries, Imo State University, Owerri, Nigeria.
}

Authors' contributions

Author LAA designed the experiment, wrote the first draft and carried out the feeding trial. Author FNM carried out the laboratory analysis while author BUE was responsible for literature. All authors read the final manuscript.

Research Article

Received 30 $0^{\text {th }}$ December 2012

Accepted $1^{\text {st }}$ March 2013

Published 24 ${ }^{\text {th }}$ August 2013

\section{ABSTRACT}

The chronic effect of feeding tigernut based diets was investigated on African catfish (Clarias garerpinus). 225 African catfish were randomly allotted to five experimental diets $(\mathrm{CP}=40 \%)$ in which tiger nut replaced maize at $0 \%, 25 \%, 50 \%, 75 \%$ and $100 \%$ respectively and fed at $3 \%$ body weight daily for a period of 20 weeks. Other water quality parameters were maintained throughout the duration of the study. Blood samples were collected from fish in replicates and analyzed for haematological and serum parameters. Results of the haematology showed no significant differences among the parameters except haemoglobin and Packed cell volume $(p<0.05)$. Similar observation was recorded for the serum biochemistry $(p>0.05)$. This trial indicated that tigernut meal can replace maize wholly in diets of African catfish without any deleterious effect on the physiology and/or health status of the fish.

Keywords: Catfish; tigernut; replacement; blood analysis. 


\section{INTRODUCTION}

Fish contributes $22 \%$ of animal protein supply in sub-Sahara Africa and $40 \%$ of animal protein consumption in Nigeria [1]. Nigeria aquaculture industry is currently faced with the problem of inadequate supply and exorbitant cost of quality fish feeds often imported [2]. Many researchers have been reported to increasing the attempts to develop practical diets for farmed fish in Nigeria by utilizing non-conventional feedstuffs with some encouragements $[3,4,5,6,7]$. However, some of these feedstuffs contained inherent anti-nutritional inhibitors which may be harmful to the animals fed such ingredients.

African catfish is the largest group of cultured species on the world after Carp, Salmonids and Tilapia. Its net production was estimated to be between $10.0-15.0 \mathrm{t} / \mathrm{ha} / \mathrm{yr}$, varying from dominated polyculture and monoculture systems. This productivity is increased with simultaneous stocking of surface feeders such as Silver carp and Catla (Catlacatla) as reported byMokhelsur and Imre [8].

Since blood tissue truly reflects the physical and chemical changes occurring in organisms, detailed information can be obtained therefore, on the general metabolism and physiological status of fish in different groups of age and habitat. Nevertheless, current reality on the use of alternative feed resources mainly to reduce cost of feed and fish has made it imperative to study the effect of feeding non-conventional feedstuff such as tigernut (Cyperus esculentus) often reported to contain some anti-nutrients such as alkaloids, saponins, Trypsin inhibitors, Tannin and phytate on the performance and/or physiological status of the fish. This experiment therefore, evaluated the haematology and serum biochemistry of African catfish fed graded levels of tigernut meal.

\section{MATERIALS AND METHODS}

\subsection{Locality}

The experiment was carried out at the fish farm complex of Federal Polytechnic, Nekede, Owerri, Nigeria.

\subsection{Experimental Fish and Management}

Two hundred and twenty-five Clarias gariepinus with mean weight $5.0 \pm 1.0 \mathrm{~g}$ were purchased from African Regional Aquaculture Centre (ARAC), Aluu, River state, Nigeria. They were acclimated for a week and feed control diet before assigning them randomly to five treatment diets at 45 fish per treatment which was replicated trice at 15 fish each in hapanet measuring $1.5 \mathrm{~m} \times 1.0 \mathrm{~m} \times 1.0 \mathrm{~m}$ in an outdoor cistern. The experimental fish were fed the test diets (Table 3) for 20 weeks at $3 \%$ body weight daily. Stale water was often drained off pond and re-filled from the bore-hole water at the farm complex. Water chemistry was monitored and maintained as outline by Boyd [9].

\subsection{Haematological Evaluation}

At the end of the feeding trial, two fish were taken from each of the replicates and put in water in separate bowls and labeled. Fish were tranquilized with $150 \mathrm{mg} /$ litre of tricane methane sulphonate (MS222) according to Osuigwe et al. [10]. Blood samples were collected by severing the caudal peduncle of the fish using heparinized tubes, but samples 
for blood plasma was obtained by centrifuging $5 \mathrm{ml}$ of the whole blood for 3 minutes and then the supernatant plasma was collected and stored in plastic tubes at $-20^{\circ} \mathrm{C}$ for analysis.

Haemoglobin $(\mathrm{Hb})$ concentration was determined by the Cyanmethaemoglobin method by Dacie and Lewis [11] while the parked cell volume and total plasma protein were determined according to the procedure described Siwicki and Anderson [12]. The red and white blood cell counts were determined using Neubauer chamber. Mean corpuscular volume (MCV) and mean corpuscular haemoglobin $(\mathrm{MCH})$ were obtained according to the method of Dacie and Lewis [11]. Glucose and Urea were determined using UV spectrophotometer (Schimatxu UV-1200) following the procedure of Henry [13] and Bergmeyer [14].

\section{RESULTS}

Results of haemotological characteristics of trial fish is shown in Table1.

\subsection{Packed Cell Volume (\%)}

The values of $44.7,39.7,38.7,38.0$ and $40.0 \%$ were recorded for dietary treatments $0 \%$, $25 \%, 50 \%, 75 \%$ and $100 \%$ respectively. There was a significant difference $(p<0.05)$ between catfish fed control diet ( $0 \%)$ and those fed tigernut based diets.

\subsection{Haemoglobin $(g / d l)$}

The highest value of 13.4 was recorded from the control group while the least value of $11.3 \%$ was obtained from $75 \%$ tigernut based diet. There was a significant difference between the control group and those fed the tigernut based diets $(p<0.05)$.

\subsection{Red Blood Cell $\left(10^{6} / \mathrm{mm}^{3}\right)$}

The values ranged from 2.15 in control group to 1.75 in dietary treatment with $75 \%$ tigernut inclusion. There was no significant difference among the treatments $(p>0.05)$.

\subsection{White Blood Cell $\left(10^{6} \mu \mathrm{l}\right)$}

The highest value of 9850 was recorded from fish fed $75 \%$ tigernut diet while the least value of 8410 was recorded from catfish fed $25 \%$ tigernut diet. There was no significant differences $(p>0.05)$ among the treatments.

\subsection{Mean Cell Volume (fl)}

The mean cell volumes are $178.9,218.1,199.5,176.7$ and $212.4 \mathrm{fc}$ for catfish on diets $0 \%$, $25 \%, 50 \%, 75 \%$ and $100 \%$ tigernut inclusion respectively. There was no significant difference ( $p>0.05)$ among the treatments.

\subsection{Mean Cell Haemoglobin Concentration (\%)}

The values were $29.97,29.80,29.70,29.70$ and $29.0 \%$ for catfish fed diets containing $0 \%$, $25 \%, 50 \%, 75 \%$ and $100 \%$ tigernut meal. There was no significant difference among the treatment groups ( $p>0.05)$. 


\subsection{Neutrophil (\%)}

The neutronphil values were $19.4,19.6,14.5,15.3$ and $15.4 \%$ for dietary treatments $0 \%$, $25 \%, 50 \%, 75 \%$ and $100 \%$ respectively. There was no significant difference between catfish fed control $(0 \%)$ diet and those fed $25 \%$ tigernut diet $(p>0.05)$ but were significantly different from those fed diets with tigernut beyond $25 \%$ level of inclusion $(p<0.05)$.

\subsection{Monocyte (\%)}

The lymphocyte values was highest in control $(0 \%)$ group with value of $1.9 \%$ while least value of $1.2 \%$ was recorded from catfish fed $50 \%$ tigernut diet. There was no significant difference between value obtained from the control $(0 \%)$ group and those fed tigernut based diets $(p>0.05)$.

\subsection{Lymphocyte (\%)}

The lymphocyte values ranged from $78.7 \%$ in control $(0 \%)$ group to $84.3 \%$ at $50 \%$ dietary inclusion. There was no significant difference between catfish fed control $(0 \%)$ diet and those fed tigernut based diets $(p>0.05)$.

\section{DISCUSSIONS}

Table 1 shows the hematological profiles of African catfish fed tigernut based diets. The erythrocytes count ranged between $1.75-2.15 \times 10^{6} / \mathrm{mm}^{3}$ is within the range of $(2.3-2.9 \times$ $\left.10^{6}\right)$ and $\left(1.5 \times 10^{6} / \mathrm{mm}^{3}\right)$ described for catfish by Gabriel et al. [15] and Adeyemo et al. [16] respectively. Similar observation were noted by Osigwe et al. [10]who recorded (1.45 $\mathrm{x}$ $10^{6} / \mathrm{mm}^{3}$ ) but below the value of $3.50 \pm 0.35 \times 10^{6} / \mu \mathrm{l}$ reported when ethanoic extracts of Garcinia kola seeds were fed to Clarias gariepinus broodstock by Dada and Ikuerowo [17].

The haemoglobin concentration ranged between 11.3-13.4g/dl. These values were slightly above the highest value of $9.60 \mathrm{~g} / 100 \mathrm{ml}$ recorded by Omitoyin [18] for African catfish juvenile fed poultry litter and $10.62 \mathrm{~g} / 100 \mathrm{ml}$ reported by Osigwe et al. [10] who fed Clarias gariepinus with Jackbean meal based diets but in agreement with findings of Adeyemo [19].

The packed cell volume (PVC) was highest in the control group (44.7\%) while the least value of $38.0 \%$ was recorded in catfish group fed tigernut at $75 \%$ dietary inclusion $(P>0.05)$. These values were above $36.0 \%$ reported by Adeyemo [19], Erondu et al. [20]; Musa and Omoregie [21] who reported a range of $27.58-35.50 \%$ but is within the normal range of $50 \%$ for fish (Clark et al. [22]).

The leucocytes values were similar in all treatments $(p>0.05)$. The highest value of $9850 x$ $10^{6} \mu \mathrm{l}$ was obtained from catfish fed $50 \%$ tigernut based diet while the lowest value was 8410 $\times 10^{6} \mu \mathrm{l}$ catfish group on $25 \%$ dietary treatment. These values were similar to finding of Dada and Ikuerowo [17]. Nevertheless, the mean cell haemoglobin concentration (MCHC) reported in this study $(29.9 \pm 0.2 \%)$ is slightly below the value of $33.97 \%$ recorded by Adeyemo [19] and Docan et al. [23] for African catfish and Silurus glanis (European catfish) juvenile. This may be due to species differences and age of the fishes that greatly influences value of blood profile and/or haematological indices (Docan et al. [23]). 
The serum biochemistry of the African catfish fed tigernut based diets (Table 2) were similar in all indices. The catfish fed test ingredients have similar values with control fish $(p>0.05)$. This perhaps was among the reasons why there was relatively no significant differences in the nutrients utilization among treatments. Blood composition is usually altered during diseases or malnutrition conditions as documented by Feist et al. [24].

Table 1.Haematology of African catfish fed with tigernut based diets

\begin{tabular}{lllllll}
\hline Parameters & \multicolumn{7}{c}{ Dietary inclusion } \\
\cline { 2 - 7 } & $\mathbf{0 \%}$ & $\mathbf{2 5 \%}$ & $\mathbf{5 0 \%}$ & $\mathbf{7 5 \%}$ & $\mathbf{1 0 0 \%}$ & SEM \\
\hline Haemoglobin (g/dl) & $13.4^{\mathrm{a}}$ & $11.9^{\mathrm{b}}$ & $11.6^{\mathrm{b}}$ & $11.3^{\mathrm{b}}$ & $11.9^{\mathrm{b}}$ & 0.17 \\
Packed cell volume $(\%)$ & $44.7^{\mathrm{a}}$ & $39.7^{\mathrm{b}}$ & $38.7^{\mathrm{b}}$ & $38.0^{\mathrm{b}}$ & $40.0^{\mathrm{b}}$ & 0.11 \\
White blood cell $(\mathrm{mm})^{3)}$ & $9250^{\mathrm{a}}$ & $8410^{\mathrm{a}}$ & $9850^{\mathrm{a}}$ & $8642^{\mathrm{a}}$ & $9810^{\mathrm{a}}$ & 2.35 \\
Red blood cell $\left(10^{12} / \mathrm{\mu l}\right)$ & $2.15^{\mathrm{a}}$ & $1.82^{\mathrm{a}}$ & $1.94^{\mathrm{a}}$ & $1.75^{\mathrm{a}}$ & $1.93^{\mathrm{a}}$ & 0.02 \\
Mean cell volume (fl) & $178.9^{\mathrm{a}}$ & $218.1^{\mathrm{a}}$ & $199.5^{\mathrm{a}}$ & $176.7^{\mathrm{a}}$ & $212.4^{\mathrm{a}}$ & 1.10 \\
MCHC (\%) & $29.97^{\mathrm{a}}$ & $29.8^{\mathrm{a}}$ & $29.7^{\mathrm{a}}$ & $29.7^{\mathrm{a}}$ & $29.0^{\mathrm{a}}$ & 0.01 \\
Neutrophil (\%) & $19.4^{\mathrm{a}}$ & $19.6^{\mathrm{a}}$ & $14.5^{\mathrm{b}}$ & $15.3^{\mathrm{b}}$ & $15.4^{\mathrm{b}}$ & 0.03 \\
Lymphocytes (\%) & $78.7^{\mathrm{a}}$ & $80.7^{\mathrm{a}}$ & $84.3^{\mathrm{a}}$ & $83.0^{\mathrm{a}}$ & $83.2^{\mathrm{a}}$ & 0.06 \\
Monocytes (\%) & $1.9^{\mathrm{a}}$ & $1.4^{\mathrm{a}}$ & $1.2^{\mathrm{a}}$ & $1.7^{\mathrm{a}}$ & $1.4^{\mathrm{a}}$ & 0.01 \\
Eosinophils (\%) & 0 & 0 & 0 & 0 & 0 & - \\
Basophils (\%) & 0 & 0 & 0 & 0 & 0 & - \\
\hline \multicolumn{2}{c}{ ab means within rows with different superscripts are significantly different $(P<0.05)}$. &
\end{tabular}

Table 2. Serum biochemistry of African catfish fed tigernut based diets

\begin{tabular}{lllllll}
\hline \multirow{2}{*}{ Parameters } & \multicolumn{5}{c}{ Dietary inclusion } \\
\cline { 2 - 7 } & $\mathbf{0 \%}$ & $\mathbf{2 5 \%}$ & $\mathbf{5 0 \%}$ & $\mathbf{7 5 \%}$ & $\mathbf{1 0 0 \%}$ & SEM \\
\hline Total Protein $(\mathrm{g} / \mathrm{dl})$ & $68.0^{\mathrm{a}}$ & $63.0^{\mathrm{a}}$ & $67.0^{\mathrm{a}}$ & $66.0^{\mathrm{a}}$ & $69.0^{\mathrm{a}}$ & 0.51 \\
Albumin $(\mathrm{g} / \mathrm{dl})$ & $28.0^{\mathrm{a}}$ & $28.0^{\mathrm{a}}$ & $27.0^{\mathrm{a}}$ & $26.0^{\mathrm{a}}$ & $29.0^{\mathrm{a}}$ & 0.07 \\
Creatine $(\mathrm{mg} / \mathrm{dl})$ & $0.23^{\mathrm{a}}$ & $0.21^{\mathrm{a}}$ & $0.21^{\mathrm{a}}$ & $0.21^{\mathrm{a}}$ & $0.3^{\mathrm{a}}$ & 0.01 \\
Urea $(\mathrm{mg} / \mathrm{dl})$ & $6.0^{\mathrm{a}}$ & $6.0^{\mathrm{a}}$ & $5.5^{\mathrm{a}}$ & $5.5^{\mathrm{a}}$ & $5.3^{\mathrm{a}}$ & 0.00 \\
Cholesterol $(\mathrm{mg} / \mathrm{dl})$ & $148^{\mathrm{a}}$ & $159^{\mathrm{a}}$ & $178^{\mathrm{b}}$ & $168^{\mathrm{b}}$ & $175^{\mathrm{b}}$ & 13.23 \\
Total Bilirubin (mg/dl) & $0.70^{\mathrm{a}}$ & $0.74^{\mathrm{a}}$ & $0.69^{\mathrm{a}}$ & $0.72^{\mathrm{a}}$ & $0.78^{\mathrm{a}}$ & 0.00 \\
D. Bilirubin mg/dl & $0.12^{\mathrm{a}}$ & $0.12^{\mathrm{a}}$ & $0.15^{\mathrm{a}}$ & $0.12^{\mathrm{a}}$ & $0.12^{\mathrm{a}}$ & 0.00 \\
\hline \multicolumn{2}{c}{${ }^{a b} \mathrm{means}$ within rows with different superscripts are significantly different $(P<0.05)$}
\end{tabular}

Table 3. Proximate composition of tigernut based diets fed to Catfish (Clarias gariepinus)

\begin{tabular}{|c|c|c|c|c|c|}
\hline \multirow[t]{2}{*}{ Parameters } & \multicolumn{5}{|c|}{ Tigernut dietary Inclusion (\%) } \\
\hline & 0 & 25 & 50 & 75 & 100 \\
\hline Moisture & 8.93 & 9.12 & 9.76 & 9.17 & 9.75 \\
\hline Ash & 9.26 & 8.79 & 9.78 & 10.37 & 10.90 \\
\hline Crude fat & 1.48 & 5.34 & 5.84 & 6.54 & 7.30 \\
\hline Crude fiber & 4.28 & 4.31 & 4.84 & 5.52 & 5.96 \\
\hline Crude Protein & 40.11 & 40.06 & 38.60 & 38.36 & 37.34 \\
\hline Nitrogen Free Extract & 35.94 & 32.38 & 31.15 & 30.04 & 28.75 \\
\hline
\end{tabular}


Table 4. Composition of experimental diets fed to African catfish (Clarias gariepinus)

\begin{tabular}{|c|c|c|c|c|c|}
\hline \multirow[t]{2}{*}{ Ingredients } & \multicolumn{5}{|c|}{ Tigernut dietary inclusion (\%) } \\
\hline & $\mathbf{0}$ & 25 & 50 & 75 & 100 \\
\hline Maize & 25.0 & 18.75 & 12.50 & 6.25 & \\
\hline Tiger nut & - & 6.25 & 12.50 & 18.75 & 25.0 \\
\hline Soybean Meal & 25.0 & 25.0 & 25.0 & 25.0 & 25.0 \\
\hline Fish Meal & 20.0 & 20.0 & 20.0 & 20.0 & 20.0 \\
\hline Groundnut Meal & 10.0 & 10.0 & 10.0 & 10.0 & 10.0 \\
\hline Blood Meal & 10.0 & 10.0 & 10.0 & 10.0 & 10.0 \\
\hline Spent Grain & 5.0 & 5.0 & 5.0 & 5.0 & 5.0 \\
\hline Bone Meal & 2.0 & 2.0 & 2.0 & 2.0 & 2.0 \\
\hline Vit/Premix & 0.25 & 0.25 & 0.25 & 0.25 & 0.25 \\
\hline Lysine & 0.25 & 0.25 & 0.25 & 0.25 & 0.25 \\
\hline Methionine & 0.25 & 0.25 & 0.25 & 0.25 & 0.25 \\
\hline Vegetable Oil & 2.0 & 2.0 & 2.0 & 2.0 & 2.0 \\
\hline Salt & 0.25 & 0.25 & 0.25 & 0.25 & 0.25 \\
\hline Total & 100.0 & 100.0 & 100.0 & 100.0 & 100.0 \\
\hline
\end{tabular}

Aletor and Egberongbe [25] reported that red blood cell counts and PCV are mostly affected by dietary treatment. Under normal conditions, the blood profile is reasonably constant for any species with changes falling with fairly narrow limit as observed in this study [26]. Based on this experimental observation, the improved utilization of tigernut by the trial fish when compared with broilers [27] may be due to the medium where fish lives hence encouraging leaching of phenols and other anti-nutrients thereby allowing proper utilization/growth of fish without compromising the health status.

\section{CONCLUSION}

The result of this study has indicated that tigernut meal can replace maize wholly in diets of African catfish without any deleterious effect on the physiology and/or health status of the fish.

\section{COMPETING INTERESTS}

Authors have declared that no competing interests exist.

\section{REFERENCES}

1. FAO.Food and Agriculture Organization. In:The state of food insecurity in the world (Sofi2003)Rome, Italy; 2003.

2. Omitoyin BO. Problems and prospect of fish feed production in Nigeria. Invited technical paper presented at the USAID aquaculture marketing stakeholder forum held at University of Ibadan conference centre. $13^{\text {th }}$ December, 2005;3pp

3. Eyo AA. The requirement for formulatingstandard artificial fish feed. Paper presented at the 11th Annual Conference of the fisheriessociety of Nigeria (FISON) held at the Lagos State Auditorium Secretariat Alausalkeja, Lagos State. 22nd - 24th February, $1994 ; 15 p$ 
4. Fagbenro OA, Adebayo OT. An overview of the animal feed industry in Nigeria. In livestock and fish feeds in sub-Sahara Africa. FAO Fisheries Technical paper: FAO, Rome; 2002.

5. Fagbenro AO, Adeparusi E. Feedstuff and dietary substitution for farmed fish in Nigeria. Paper presented at Pan African Fish and Fisheries Conference Contonou, Benin Republic. Book of abstracts.2003;P276.

6. Gabriel UU, Akinrotimi OA, Bekibele DO, Onunkwo DN, Anyanwu PE. Locally produced fish feed, potentials for aquaculture development in sub-Sahara African. Journal of Agricultural Research. 2007;297:287-295

7. Agbabiaka LA. Evaluation of some under utilized protein feedstuffs in diets of Clarias gariepinus fingerlings. International Journal of Tropical Agric. and Food systems. 2010;4(1):10-12.

8. Mokhlesur MR,Imre V. Culture of African Magur (Clarias gariepinus) in Bangladesh. FAO field Document BGD/87/045/92/19; 1992.

9. Boyd CE.Water quality in warm water fish ponds. Auburn University, Alabama Agric. experimental Station. 1979;359pp.

10. Osuigwe DI, Obiekezie Al, Onuoha GC. Some haematological changes in hybrid catfish (Heterobranchus longifilis x Clarias gariepinus) fed different dietary levels of raw and boiled jackbean (Canavalia ensiformis) seed meal. African Journal of Biotechnology. 2005;4(9):1017-1021

11. Dacie-Lewis JV, Lewis SM. Practical Haematology. Longman Group Ltd. 1976;78-97

12. Siwicki AK, Anderson DP. Immune-simulation in fish; measuring the effects of stimulants by scrological and immunological methods. Nordic Symp. Fish Immunology. Lysekil. 1993;19-22.

13. Henry RJ. Clinical Chemistry, principles and techniques. New York; Harper \& Row; 1974.

14. Bergmeyer HU. Methods of enzymatic analysis,Deerfield Beach; VCH; 1986.

15. Gabriel UU, Ezeri GNO, Opabunmi OO. Influence of sex, source, health status and acclimation on the haematology of Clarias gariepinus (Bruchell 1822). African Journal of Biotech.2004;3(9):163-467.

16. Adeyemo O, Agbede SA, Olaniyan AO, Shoaga OA. The haematological response of Clarias gariepinus to change in acclimation temperature. Afri. J. of Biomed. Res. 2003;6:105-108

17. Dada AA,lkuerowo M. Effect of ethanoic extracts of Garcinia kola seeds on growth and haematology of catfish (Clarias gariepinus) broodstock. African Journal of Agricultural Research. 2009;4(4):344-347

18. Omitoyin BO. Haematological changes in the blood of Clarias gariepinus (Burchell 1822) juvenile fed poultry litter. Livestock research for rural development. 2006;18(11):1-6.

19. Adeyemo OK. Haematological profile of Clarias gariepinus (Burchell 1822) exposed to lead. Turkish Journal of Fisheries and Aquatic Sciences. 2007;7:163-169

20. Erondu ES, Nnubia S, Nwanukwe FO. Haematological studies on four catfish species raised in fresh water pond in Nigerian Journal of Applied Ichthyology. 1993;9(3-4):250256

21. Musa SO, Omoregie E. Haematological changes in mudfish, Clarias gariepinus, (Bruchell 1822) exposed to malachite green. Journal of Aquatic. Science. 1999;14:3742.

22. Clark S, Whitemore DH Jr, McMahon RF. Consideration of blood parameters of largemouth bass (Micropterus salmoides). J. Fish Biol. 1979;14:147-154 
23. Docan A, Cristea V, Grecu L, Dediu L. Haematological response of the Europen catfish, Silurus glarus reared at different densities in flow through production system. Archive Zootechnica. 2010;13(2):63-70

24. Feist SW, Longshaw M. Myxosporiodiosis of fish and the Bryozoan link with proliferate kidney diseases (PKD) of Salmonids. Journal of Fish Diseases. 2000;1:91-108

25. Aletor VA, Egberongbe $O$. Feeding differently processed soybean and haematological indices in the chicken diet. $5^{\text {th }}$ Edition J. Poultry Sci. 1998;(3):34-36

26. Banergee SK, Patra BC, Bandeypahyay P, Teway A. Changes of blood parameter in carp, Catlacatla. J. Aquatic Biol. 2002;17(11)79-84

27. Agbabiaka LA. Evaluation of tigernut meal (Cyperus esculentus $L$ ) as replacement for maize in diets of broiler chicks and African catfish (Clarias gariepinus Burchell, 1822). Ph.D Thesis, Department of Animal Science and Fisheries. Imo State University, Owerri. Nigeria. 2012;174p.

(C) 2013 Agbabiaka et al.; This is an Open Access article distributed under the terms of the Creative Commons Attribution License (http://creativecommons.org/licenses/by/3.0), which permits unrestricted use, distribution, and reproduction in any medium, provided the original work is properly cited.

Peer-review history:

The peer review history for this paper can be accessed here: http://www.sciencedomain.org/review-history.php?iid=236\&id=2\&aid=1910 